\title{
KEWENANGAN PANITIA PENGAWAS PEMILIHAN UMUM DALAM PEMILIHAN KEPALA DAERAH
}

\author{
NOVA YARSINA \\ Sekolah Tinggi Ilmu Hukum Putri Maharaja Payakumbuh \\ novayarsina@yahoo.com
}

\begin{abstract}
Election implementation by Panwaslu cannot play an effective role in supervising every stage of the Provincial and Regency / City Pilkada. There are obstacles faced by the District / City Panwaslu and the District Panwaslu in carrying out their roles, namely by the regulation of authority that limits all forms of Panwaslu actions in the implementation of Pilkada. The Provincial Panwaslu to the level of the Field Supervisory Committee (PPL) in the exercise of its authority will make efforts to the community such as taking action to inform people about how to exercise the authority to supervise the implementation of the Provincial and Regency / City Pilkada, so as to create an honest, fair, and regional election democratic depends on the extent to which the General Election Supervisory Committee works well and ensures the smooth running of Regional Head Elections that take place in a democratic manner.
\end{abstract}

Keywords: Election Supervisory Committee, Regional Head Election.

Abstrak: penyelenggaraan Pemilu oleh Panwaslu tidak bisa berperan secara efektif dalam hal melakukan pengawasan disetiap tahapan Pilkada Provinsi dan di Kabupaten/Kota. Terdapat hambatan-hambatan yang dihadapi oleh Panwaslu Kabupaten/Kota maupun Panwaslu Kecamatan dalam menjalankan perannya, yaitu dengan adanya pengaturan wewenang yang membatasi segala bentuk tindakan Panwaslu dalam pelaksanaan Pilkada. Panwaslu Provinsi hingga tingkat Panitia Pengawas Lapangan (PPL) dalam pelaksanaan wewenangnya akan melakukan upaya terhadap masyarakat seperti, melakukan tindakan pemberitahuan tentang bagaimana pelaksanaan wewenang melakukan pengawasan terhadap pelaksanaan Pilkada Provinisi dan di Kabupaten/Kota, sehingga tercipta Pemilihan Kepala Daerah yang jujur, adil, dan demokratis tergantung pada sejauh mana Panitia Pengawas Pemilihan Umum bekerja dengan baik dan menjamin kelancaran Pemilihan Kepala Daerah yang berlangsung secara demokratis.

Kata Kunci: Panitia Pengawas Pemilu, Pemilihan Kepala Daerah.

\section{A. Pendahuluan}

Dalam perkembangan demokrasi di Indonesia pasca runtuhnya orde baru hingga saat ini telah mengembangkan pemikiran dari rakyat untuk mengimplementasikan asas kedaulatan rakyat dengan berbagai cara "sehingga dalam setiap sendi kehidupan bernegara nilai-nilai kedaulatan rakyat selalu menjadi jantung yang memompa darah keseluruh tubuh kenegaraan Republik Indonesia", selama ini rakyat merasa bahwa kedaulatan mereka hanya terbatas pada partisipasi mereka dalam pemilu untuk memilih anggota legislatif yang merupakan perwujudan wakil rakyat, sehingga rakyat menuntut agar peranan rakyat tidak hanya terbatas pada lingkup pemilihan legislatif saja melainkan juga lingkup pemilihan lembaga eksekutif mulai dari lingkup lembaga eksekutif tertinggi yaitu presiden, sampai pemilihan Kepala Daerah (Lili Romli, 2007). 
Pemilihan Umum (PEMILU) secara langsung oleh rakyat merupakan sarana perwujudan kedaulatan rakyat guna menghasilkan pemerintahan Negara yang demokratis berdasarkan Pancasila dan Undang-Undang Dasar 1945. Undang-Undang Dasar 1945 dalam Pasal 1 ayat (2) menyatakan bahwa "Kedaulatan berada di tangan rakyat dan dilaksanakan menurut Undang-Undang Dasar". Penyelenggaraan Pemilihan Umum secara langsung, umum, bebas, rahasia, jujur dan adil dapat terwujud apabila dilaksanakan oleh penyelenggara Pemilihan Umum yang mempunyai integritas, profesionalisme dan akuntabilitas (Suharizal, 2011).

Akuntabiltas berarti setiap pihak yang terlibat dalam penyelenggaraan Pemilu harus mempertanggung jawabkan pelaksanaan tugas dan kewenangannya kepada publik baik secara politik maupun secara hukum. Bertanggung jawab secara politik berarti setiap unsur yang terlibat dalam penyelenggaraan Pemilu mempunyai kewajiban menjelaskan kepada masyarakat fungsinya dan alasan tindakan yang diambil. Bertanggung jawab secara hukum berarti setiap pihak yang diduga melakukan pelanggaran hukum perihal asas-asas Pemilu yang demokratis wajib tunduk pada proses penegakan hukum (Suharizal, 2011).

Selain dari itu Undang-Undang Dasar kita menyebut dua (2) prinsip yang menjiwai naskah itu dan yang dicantumkan dalam penjelasan mengenai Sistem Pemerintahan, suatu Negara. yaitu: 1) Indonesia ialah Negara yang berdasarkan atas hukum (Rechstaat). Negara Indonesia berdasarkan atas hukum (Rechstaat), tidak berdasarkan kekuasaan belaka (Machstaat) dan 2) Sistem Konstitusionil. Pemerintahan berdasarkan atas Sistem Konstitusi (Hukum Dasar), tidak bersifat Absolutisme (kekuasaan yang tidak terbatas). Berdasarkan 2 istilah Rechstaat dan sistem konstitusi, maka jelaslah bahwa demokrasi yang menjadi dasar dari Undang-Undang Dasar 1945, ialah demokrasi konstitusionil. Di samping itu corak khas demokrasi Indonesia, yaitu kerakyatan yang dipimpin oleh hikmat kebijaksanaan dalam permusyawaratan perwakilan, dimuat dalam Pembukaan Undang-Undang Dasar 1945.

Demikian demokrasi Indonesia mengandung arti di samping nilai umum, dituntut nilai-nilai khusus seperti nilai-nilai yang memberikan pedoman tingkah laku manusia Indonesia dalam hubungannya dengan Tuhan Yang Maha Esa, sesama manusia. Tanah air dan Negara Kesatuan Republik Indonesia, pemerintah dan masyarakat, usaha dan manusia dalam mengolah lingkungan hidup. Pada kebanyakan Negara demokrasi, Pemilihan Umum dianggap lambang, sekaligus tolak ukur, dari demokrasi itu. Hasil Pemilihan Umum yang diselenggarakan dalam suasana keterbukaan dengan kebebasan berpendapat dan berserikat, dianggap mencerminkan partisipasi serta aspirasi masyarakat (Miriam Budiarjo. 2008). Pemilihan Umum merupakan sebuah agenda nasional di Negara Kesatuan Republik Indonesia yang dilaksanakan satu kali dalam lima tahun, sekaligus sebagai implementasi dari amanat Undang-undang Dasar 1945. Untuk pelaksanaan Pemilihan Umum tersebut Pemerintah Republik Indonesia membentuk suatu lembaga yang disebut dengan Komisi Pemilihan Umum (KPU) sebagai lembaga penyelenggara Pemilihan Umum bersama Badan Pengawas Pemilihan Umum (BANWASLU) Republik Indonesia yang ditetapkan melalui Undang-Undang tentang Pemilihan Umum.

Lembaga penyelenggara Pemilihan Umum tersebut berkedudukan di pusat, Provinsi, serta di Kabupaten/Kota di seluruh Indonesia. Sementara untuk melakukan pengawasan terhadap penyelenggaraan Pemilihan Umum dilakukan oleh Badan Pengawas Pemilihan Umum untuk tingkat pusat, Panitia Pengawas Pemilu 
(PANWASLU) Provinsi untuk penyelenggaraan Pemilihan Umum di Provinsi dan Panitia Pengawas Pemilihan Umum Kabupaten/Kota untuk Pelaksanaan Pengawasan penyelenggaraan Pemilihan Umum di tingkat Kabupaten/Kota (Miriam Budiarjo. 2008). Melalui Pemilihan Umum rakyat dapat menentukan sikap politiknya untuk tetap percaya pada pemerintah lama atau menggantikannya dengan yang baru. Dengan kata lain Pemilihan Umum merupakan sarana penting dalam mempromosikan dan meminta akuntabilitas dari pejabat publik. Melalui Pemilihan Umum diharapkan proses politik yang berlangsung akan melahirkan suatu pemerintahan baru yang sah, demokratis dan benar-benar mewakili kepentingan masyarakat.

Oleh karena itu salah satu persyaratan penting dalam penyelenggaraan Pemilihan Umum Negara Demokrasi adalah penyelenggara Pemilihan Umum dilaksanakan oleh lembaga yang mandiri dari pemerintah (Ahmad Nadir. 2005). Lembaga ini dibentuk untuk memperkuat pilar demokrasi dan meminimalisir terjadinya kecurangan dalam pemilihan Kepala Daerah. Ciri-ciri utama dari personil pengawasan pemilihan Kepala Daerah yang independen atau mandiri adalah (Ahmad Nadir. 2005): 1) Dibentuk berdasarkan perintah konstitusi atau undang-undang; 2) Tidak mudah diintervensi oleh kepentingan politik tertentu, 3) Bertanggung jawab kepada pemerintah, 4) Menjalankan tugas sesuai dengan tahapan Pilkada, 5) Memiliki integritas dan moralitas yang baik dan, 6) Memahami tata cara penyelenggara Pilkada.

Panitia Pengawas Pemilihan Umum Kepala Daerah tidak hanya bertanggung jawab terhadap pembentukan pemerintah yang demokratis, tetapi juga ikut adil dalam membuat rakyat memilih kandidat Kepala Daerah yang mereka anggap mampu, dalam hal tersebut sejauh ini masih banyak yang meyakini Pemilu bisa berjalan demokratis jika ada pengawasan yang dilakukan secara terbuka, jujur dan adil. Untuk menciptakan Pemilihan Umum Kepala Daerah yang bersih diperlukan pengawasan yang efektif, Efektifitas pengawasan Pemilihan Umum Kepala Daerah ditentukan oleh para pengawas dalam memahami dan mengerti bagaimana proses pengawasan itu dijalankan dengan baik (Topo Santoso. 2007).

Adapun bentuk Pengawasan Pemilu adalah kegiatan untuk mengamati, mengkaji, memeriksa dan menilai proses penyelenggaraan pesta demokrasi atau pemilu sesuai dengan peraturan perundang-undangan yang berlaku. Pelaksanaan Pengawasan Pemilu berpedoman kepada asas, mandiri, jujur, adil, kepastian hukum, tertib penyelenggaraan, kepentingan umum, keterbukaan, proposional, akuntabilitas, efektif dan efisien. Dan Pelaksanaan Pengawasan Pemilu Kepala Daerah dan Wakil Kepala Daerah Kabupaten/Kota dilaksanakan oleh Panwaslu Kabupaten/Kota, Panitia Pengawas Kecamatan, dan Pengawas Pemilu Lapangan. Dengan demikian Panwaslu merupakan pilar inti dalam penyelenggaraan Pemilihan Kepala Daerah, karena Pemilihan Kepala Daerah yang jujur, adil, dan demokratis sangat tergantung pada sejauh mana Panitia Pengawas Pemilihan Umum bekerja dengan baik dan menjamin Pemilihan Kepala Daerah berlangsung secara demokratis.

\section{B. Metodogi Penelitian}

Pendekatan yang digunakan dalam penelitian ini adalah bersifat yuridis normatif yang menekankan pada penelitian terhadap taraf sinkronisasi hukum. Dalam penelitian terhadap taraf sinkronisasi hukum ini yang diteliti adalah sampai sejauh mana hukum positif tertulis yang ada satu sama lainnya. Hal ini dapat dilakukan melalui secara aspek hukum, melihat apakah suatu peraturan perundang-undangan yang berlaku bagi suatu bidang kehidupan tertentu tidak saling bertentangan antara satu dengan yang lainnya apabila dilihat dari sudut peraturan perundang-undangan yang ada. E-ISSN: 2657-0300 $\quad$ Lembaga Penelitian dan Penerbitan Hasil Penelitian Ensiklopedia 299 
Permasalahan ditujukan pada Pelaksanaan Panitia Pengawas Pemilihan Umum terhadap Pemilihan Kepala Daerah.

\section{Hasil dan Pembahasan}

Setiap daerah harus dipimpin oleh seorang Kepala Daerah. Itulah sebabnya tidak satupun daerah di Indonesia, baik Provinsi maupun Kabupaten /Kota yang tidak memiliki Kepala Daerah. Sekalipun daerah tersebut baru dibentuk sebagai akibat dari adanya pemekaran daerah yang sudah ada sebelumnya pasti daerah tersebut sudah dipimpin oleh seorang Kepala Daerah walaupun dengan sebutan Pejabat Kepala Daerah (Pejabat Kepala Daerah, Pejabat Bupati/Walikota) (Abdullah Rozali, 2005). Sistem demokrasi modren pada dasarnya hanya mengenal dua tipe dalam kepemimpinan yaitu melalui jalur konstitusional dan inkonstitusional. Baik pada skala global maupun dalam skala lokal, pilihan melalui mekanisme pemilu merupakan hal yang paling umum dan beresiko sosiopolitik yang terukur. Itulah sebabnya jalur pemilu dengan melibat kan seluruh komponen masyarakat untuk ikut berpartisipasi tetap merupakan mekanisme yang lebih elegan dalam memproduksi pemimpin politik yang diharapkan. Sekalipun pemilihan Kepala Daerah sering diperdebatkan apakah termasuk pemilu atau merupakan bagian dari pemerintahan daerah yang dianggap tidak terlalu penting pengaruhnya. Demikian pula halnya adanya anggapan apakah pemilihan Kepala Daerah.

Dalam Pemilu Kepala Daerah ada 3 (tiga) indikasi titik rawan yang perlu di cermati, yaitu: 1) Pada tahap proses pengusulan bakal calon pasangan Kepala Daerah dan Wakil Kepala Daerah. Baik dalam Pemilu Kepala Daerah Provinsi maupun pada Pemilu Kepala Daerah Kabupaten/Kota tahapan pengampunan nama bakal calon Kepala Daerah dan Wakil Kepala Daerah hingga tahap penjaringan nama bakal calon merupakan interval waktu yang sangat krusial memperoleh perhatian sangat serius; 2) Pada proses pencalonan Kepala Daerah dan Wakil Kepala Daerah oleh partai politik. Secara teoritis hal ini dimasukkan ke dalam implementasi dalam rekruitmen politik yang dilakukan oleh partai politik; 3) Pada tahap pemungutan suara sampai dengan saat penetapan pasangan bakal calon Kepala Daerah dan Wakil Kepala Daerah oleh KPU. Itulah sebabnya jika dicermati berbagai titik rawan tersebut dalam pelaksanaan pemilihan Kepala Daerah dan Wakil Kepala Daerah juga harus dilengkapi dengan berbagai instrumen aturan main yang lengkap. Bahkan ada aturan yang lengkap jika tidak di barengi dengan adanya kemauan dan keinginan yang kuat antara Komisi Pemilihan Umum, peserta pemilihan Kepala daerah dan Panitia Pengawas untuk menyelenggarakan Pemilihan Kepala Daerah dan Wakil Kepala Daerah yang bersih, jujur dan adil akan sulit dilaksanakan.

Fungsi Pengawas Pemilu yang dijabarkan dalam tugas, wewenang dan kewajiban Pengawas Pemilu. Berkaitan dengan tugas pengawasan pemilu ada pembagian tugas pengawasan pemilu yang dapat dijelaskan sebagai berikut: a) Bawaslu melakukan pengawasan terhadap seluruh tahapan penyelenggaraan Pemilu; b) Panwaslu Provinsi mengawasi tahapan penyelenggaraan Pemilu di wilayah Provinsi; c) Panwaslu Kabupaten/Kota mengawasi penyelenggaraan Pemilu di wilayah Kabupaten/Kota; d) Panwaslu Kecamatan mengawasi tahapan penyelenggaraan Pemilu di wilayah Kecamatan; e) Pengawas Pemilu Lapangan mengawasi tahapan penyelenggaraan Pemilu ditingkat Desa/Kelurahan; dan f) Pengawas Pemilu Luar Negeri mengawasi tahapan penyelenggaraan Pemilu di Luar Negeri. 

berikut:

Dalam Pelaksanaan wewenangnya Pengawas Pemilu berkewajiban sebagai

\begin{tabular}{|c|c|c|}
\hline No. & Kewajiban & Pengawas Pemilu \\
\hline 1. & $\begin{array}{l}\text { Bersikap tidak diskriminatif dalam menjalankan tugas dan } \\
\text { wewenangnya }\end{array}$ & $\begin{array}{l}\text { Pengawas Pemilu } \\
\text { disemua tingkatan }\end{array}$ \\
\hline 2. & $\begin{array}{l}\text { Melakukan pembinaan dan pengawasan terhadap } \\
\text { pelaksanaan tugas Pengawas Pemilu pada semua tingkatan }\end{array}$ & Bawaslu \\
\hline 3. & $\begin{array}{llll}\text { Melakukan pembinaan dan pengawasan } & \text { terhadap } \\
\text { pelaksanaan } \\
\text { dibawahnya }\end{array}$ & Panwaslu Provinsi \\
\hline 4. & $\begin{array}{l}\text { Menerima dan menindak lanjuti laporan yang berkaitan } \\
\text { dengan dugaan adanya pelanggaran terhadap pelaksanaan } \\
\text { peraturan perundang-undangan mengenai pemilu. }\end{array}$ & $\begin{array}{l}\text { Pengawas Pemilu } \\
\text { disemua tingkatan }\end{array}$ \\
\hline 5. & $\begin{array}{l}\text { Menyampaikan laporan hasil pengawasan kepada } \\
\text { presiden, DPR dan KPU sesuai dengan tahapan secara } \\
\text { periodic dan/atau berdasarkan kebutuhan. }\end{array}$ & Bawaslu \\
\hline 6. & $\begin{array}{l}\text { Menyampaikan laporan hasil pengawasan kepada Bawaslu } \\
\text { sesuai dengan tahapan Pemilu secara peridik dan/atau } \\
\text { berdasarkan kebutuhan }\end{array}$ & Panwaslu Provinsi \\
\hline 7. & $\begin{array}{l}\text { Menyampaikan temuan dan laporan kepada Bawaslu } \\
\text { berkaitan dengan adanya dugaan pelanggaran yang } \\
\text { dilakukan oleh KPU Provinsi yang mengakibatkan } \\
\text { terganggunya penyelenggaraan tahapan Pemilu di tingkat } \\
\text { provinsi. }\end{array}$ & Panwaslu Provinsi \\
\hline 8. & $\begin{array}{l}\text { Menyampaikan temuan dan laporan kepada Panwaslu } \\
\text { Provinsi berkaitan dengan adanya dugaan pelanggaran } \\
\text { yang dilakukan oleh KPU Kabupaten/kota yang } \\
\text { mengakibatkan terganggunya penyelenggaraan tahapan } \\
\text { Pemilu di tingkat Kabupaten/Kota. }\end{array}$ & $\begin{array}{c}\text { Panwaslu } \\
\text { Kabupaten/Kota }\end{array}$ \\
\hline 9. & $\begin{array}{l}\text { Menyampaikan laporan kepada Panwaslu Kabupaten/Kota } \\
\text { berkaitan dengan adanya dugaan tindakan yang } \\
\text { mengakibatkan terganggunya penyelenggaraan tahapan } \\
\text { Pemilu di tingkat Kecamatan. }\end{array}$ & $\begin{array}{l}\text { Panwaslu } \\
\text { Kecamatan }\end{array}$ \\
\hline 10. & $\begin{array}{l}\text { Menyampaikan temuan dan laporan kepada Panwaslu } \\
\text { Kabupaten/Kota berkaitan dengan adanya dugaan } \\
\text { pelanggaran yang dilakukan oleh PPK yang } \\
\text { mengakibatkan terganggunya penyelenggaraan tahapan } \\
\text { Pemilu di tingkat Kecamatan. }\end{array}$ & $\begin{array}{l}\text { Panwaslu } \\
\text { Kecamatan }\end{array}$ \\
\hline 11 & $\begin{array}{l}\text { Menyampaikan laporan kepada Panwaslu Kecamatan } \\
\text { berkaitan dengan adanya dugaan tindakan yang } \\
\text { mengakibatkan terganggunya penyelenggaraan tahapan } \\
\text { Pemilu di tingkat Kecamatan. }\end{array}$ & $\begin{array}{c}\text { Pengawas Pemilu } \\
\text { Lapangan }\end{array}$ \\
\hline 12 & $\begin{array}{l}\text { Menyampaikan temuan dan laporan kepada Panwaslu } \\
\text { Kecamatan berkaitan dengan adanya dugaan pelanggaran } \\
\text { yang dilakukan oleh PPS dan KPPS yang mengakibatkan } \\
\text { terganggunya penyelenggaraan tahapan Pemilu di tingkat } \\
\text { Desa/Kelurahan. }\end{array}$ & $\begin{array}{c}\text { Pengawas Pemilu } \\
\text { Lapangan }\end{array}$ \\
\hline
\end{tabular}


Demokrasi merupakan bentuk pemerintahan politik yang kekuasaan pemerintahannya berasal dari rakyat, baik secara langsung (demokrasi langsung) atau melalui perwakilan (demokrasi perwakilan). DPRD adalah wakil rakyat yang dipilih oleh rakyat untuk mewakili aspirasi rakyat di pemerintahan. Jika dilihat dari pengertian demokrasi itu sendiri dimana terdapat demokrasi secara tidak langsung (representatif demokrasi). Memang dimungkinkan terjadinya pemilihan kepala daerah oleh DPRD.

Namun pada saat ini masih menjadi pertentangan karena jika disandingkan juga dengan Pasal 22E ayat (1) Undang-Undang Dasar Negara Republik Indonesia Tahun 1945 yang berbunyi "Pemilihan Umum dilaksanakan secara langsung, umum, bebas, rahasia, jujur, dan adil setiap lima tahun sekali". Dalam pasal tersebut kata "langsung" ditafsirkan dan juga mengkehendaki dilakukannya pemilihan kepala daerah oleh rakyat secara langsung. Dimana setiap warga negara memiliki hak suara untuk individu yang telah memenuhi syarat. Alasan lain yang menjadi faktor lahirnya wacana ini adalah masalah finansial. Dana yang digunakan untuk setiap pemilihan kepala daerah memang terbilang besar. Jika dana tersebut dialihkan untuk memperbaiki kehidupan masyarakat tentu akan lebih baik, tetapi terdapat juga kontra untuk wacana tersebut yang memandang akan mudahnya terjadi jual beli suara antara setiap oknum yang berkepentingan untuk berkuasa di tingkat daerah.

Untuk itu perlu dikaji lebih mendalam mengenai wacana yang sedang hangat diperdebatkan di Nasional. Disamping itu sebagai bahan pembelajaran dalam materi "Pemilihan Kepala Daerah dan Wakil Kepala Daerah" maka kasus tersebut diangkat sebagai perbandingan antara teori dan fakta dilapangan. Perlu juga ditemukan solusi untuk setiap permasalahan tersebut. Penyelenggaraan Pilkada dilakukan oleh Komisi Pemilihan Umum (KPU) Provinsi dan KPU Kabupaten/Kota. Pilkada diselenggarakan dengan diawasi oleh Panitia Pengawas Pemilihan Umum (Panwaslu) Provinsi dan Panwaslu Kabupaten/Kota. Keanggotaan dari Panwaslu terdiri atas unsur kepolisian, kejaksaan, perguruan tinggi, pers, dan tokoh masyarakat

\section{Penutup}

Adapun kesimpulan yang dapat dipaparkan oleh penulis bahwa penyelenggaraan Pemilu oleh Panwaslu tidak bisa berperan secara efektif dalam hal melakukan pengawasan disetiap tahapan Pilkada Provinsi dan di Kabupaten/Kota. Terdapat hambatan - hambatan yang dihadapi oleh Panwaslu Kabupaten/Kota maupun Panwaslu Kecamatan dalam menjalankan perannya, yaitu dengan adanya pengaturan wewenang yang membatasi segala bentuk tindakan Panwaslu dalam pelaksanaan Pilkada. Panwaslu Provinsi hingga tingkat Panitia Pengawas Lapangan (PPL) dalam pelaksanaan wewenangnya akan melakukan upaya terhadap masyarakat seperti, melakukan tindakan pemberitahuan tentang bagaimana pelaksanaan wewenang melakukan pengawasan terhadap pelaksanaan Pilkada Provinisi dan di Kabupaten/Kota, sehingga tercipta Pemilihan Kepala Daerah yang jujur, adil, dan demokratis tergantung pada sejauh mana Panitia Pengawas Pemilihan Umum bekerja dengan baik dan menjamin kelancaran Pemilihan Kepala Daerah yang berlangsung secara demokratis. 


\section{Daftar Pustaka}

Lili Romli, 2007.Demokrasi Pilkada, Jakarta: LIPI.

Suharizal, 2011. Pilkada Regulasi, Dinamika, dan Konsep Mendatang, Jakarta. PT. Raja Grafindo Persada.

Miriam Budiarjo. 2008. Dasar-Dasar Ilmu Politik. PT Gramedia Pustaka Utama. Jakarta.

Ahmad Nadir. 2005. Pilkada Langsung dan Masa Depan Demokrasi di Indonesia. Averroes Press. Malang.

Topo Santoso. 2007. Hukum dan Proses Demokrasi. Kemitraan. Jakarta.

Abdullah Rozali, 2005. Pelaksanaan Otonomi Luas dengan Pemilihan Kepala Daerah Secara Langsung, Jakarta, PT. Raja Grafindo Persada. 